Journal of Southeast Asian

2015

\title{
Book Review of Caught Dead by Andrew Lanh
}

Quan-Manh $\mathrm{Ha}$

University of Montana - Missoula, quan.ha@mso.umt.edu

\section{Recommended Citation}

Ha, Quan-Manh (2015) "Book Review of Caught Dead by Andrew Lanh," Journal of Southeast Asian American Education and Advancement. Vol. 10 : Iss. 1, Article 3.

DOI: $10.7771 / 2153-8999.1122$

Available at: https://docs.lib.purdue.edu/jsaaea/vol10/iss1/3

This document has been made available through Purdue e-Pubs, a service of the Purdue University Libraries. Please contact epubs@purdue.edu for additional information.

This is an Open Access journal. This means that it uses a funding model that does not charge readers or their institutions for access. Readers may freely read, download, copy, distribute, print, search, or link to the full texts of articles. This journal is covered under the CC BY-NC-ND license. 


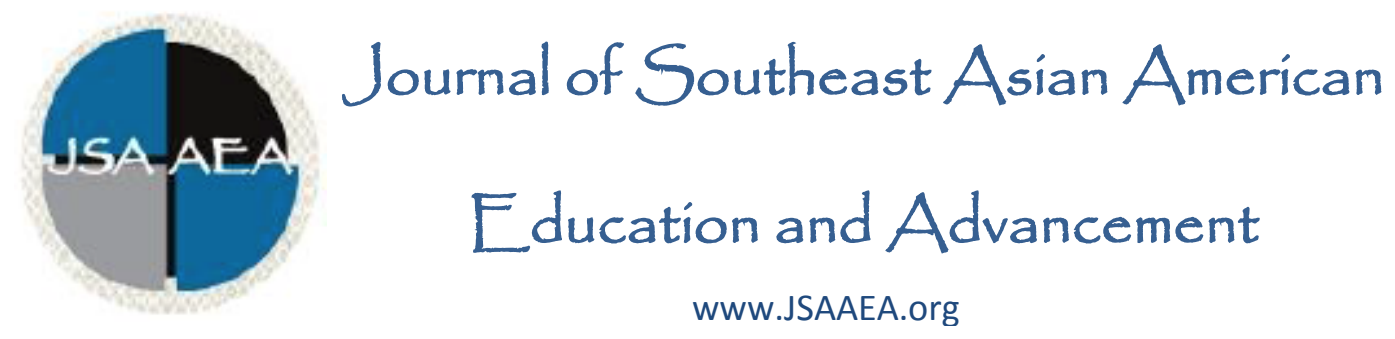

Volume 10 (2015)

\section{Book Review}

Lanh, Andrew. (2014). Caught Dead. Scottsdale, AZ: Poisoned Pen Press. 283 pp. $\$ 14.95$

(Paperback). ISBN: 978-1-4642-0332-9.

\section{Reviewed by \\ Quan-Manh Ha \\ University of Montana-Missoula}

Ed Ifkovic, who wrote Caught Dead under the pseudonym Andrew Lanh, sets his detective novel in contemporary Hartford, Connecticut. The novel's first-person narrator, Rick Van Lam, is a former New York police officer who has relocated in Hartford, where he works as a private investigator for an insurance company. In his childhood, Rick was an orphaned Amerasian who was born during the Vietnam War and came to America at the age of thirteen, under the sponsorship of the Catholic Church. He later excelled in college and earned a degree in Criminal Justice.

Rick teaches part-time at a college, where he first met Hank, a full-blooded Vietnamese male student, who becomes Rick's close friend. Caught Dead focuses on the tragic deaths of the Le twin sisters, Mary and Molly, who are known for their exceptional beauty within the Vietnamese American community, Little Saigon. The twin sisters and Hank are distant cousins, and the novel opens with the death of Mary, one of the sisters, and Hank's mother's insistence that Rick investigate the death, which took place at Goodwin Square, frequented by late-night drug dealers and gangsters.

Prior to this series of events, Mary is married to Benny Vu, owner of a small Vietnamese grocery store, and they live a middle-class life with their children, Tommy and Cindy. In contrast, Molly is married to Larry Torcelli, a wealthy Italian American businessman, and they live a privileged life with their children, Jon and Kristen. Another main character is Danny, son of a Vietnamese woman named Susie, who has been working as a maid for the Torcellis for more than twenty years. It is Larry who had financially supported Tommy, Cindy, and Danny, along with his own children, as they attended the prestigious, expensive Chesterton high school. Danny later earned a degree in Finance at Harvard, and Jon is pursuing a graduate degree at Yale. In contrast, Tommy is a "punked out druggie," his sister Cindy is an antisocial "Disney cartoon character," and their cousin Kristen is a "vain and silly girl" with "wild fantasies" (pp. 126, 197, 271).

Tommy, Jon, and Danny become estranged following a scandalous incident related to drugs, referred to as the "Opium Wars," that they were involved in during their adolescent years (p. 224). This incident continues to raise suspicion from their mothers. Danny, a successful, 
unctuous, "[h]andsome, charming, super intelligent, slick, athletic" banker and womanizer, becomes Larry's favorite, which evokes jealousy and animosity from Molly and Jon: "Molly was afraid of him [Danny], Larry adores him like the son he never had, Jon hates him because he can never be as good as Danny, and Kristen throws goo-goo eyes at him and moistens her panties" (p. 156). Caught Dead focuses attention on the complicated relationships between Danny and other characters, and in each chapter, a heartless personality is gradually revealed behind Danny's deceptively attractive physical appearance.

With the help of his ex-wife, colleagues, and friends, and after his several interviews and confrontations with the family members of the victims, Rick finally finds out that it is Danny who caused the murders of the Le twin sisters: "both done in by a hit man he'd located in New York City" (pp. 269-70). Danny is revealed as smartly manipulative, controlling, and vicious. His ambition is to become as wealthy and powerful as Larry, and he uses the charismatic power he has over people to achieve his American Dream. Suspecting that Danny offered and sold drugs to Tommy and Kristen, the Le twin sisters planned to hire a detective to investigate Danny. Afraid that the investigation would jeopardize his career at Bank of America, he must murder Mary and Molly to protect his self-interests. He stages the murder scenes of Mary and Molly so cleverly that they confuse the police, appearing as if they were "drive-by dumb accident[s]" ( $p$. 276).

Danny uses Larry's frivolous daughter, Kristen, for casual sex, and he deludes her into believing that he truly loves and wants to marry her so that she "keeps quiet about things" (p. 271). Interrogated by Rick, Kristen defends Danny's innocence because she, who possesses a "little-girl mentality" and "little-girl puppy love infatuation," is blind to Danny's Machiavellian schemes (p. 258). Ironically, at the conclusion of the novel, Larry admits that he knew it was Danny who murdered his wife and sister-in-law, but Larry dared not report Danny to the authorities: doing so would ruin Larry's lucrative business, because Danny manages his large accounts and transactions at Bank of America and he illegally networks Larry with "fake investors" to earn "real money"-amounting to millions of dollars (p. 274). Finally, Larry confesses to Rick: "I made him [Danny] that way. [...] Isn't that ironic? I made him believe he could do anything. [...] At the end I felt that Danny controlled me. I created him, and I was afraid of him" (p. 279). Danny is arrested at his workplace, but he still is a "[g]ood-looking young man," even with his cuffed hands (p. 268).

Most of the events in Caught Dead are narrated chronologically, and the writing style is quite clear and straightforward: the author does not use ornate language, and the novel's characters converse informally. Lanh italicizes Vietnamese words and phrases when he describes Vietnamese cuisine or common expressions, and he then provides their English equivalents. Caught Dead effectively employs such fundamental elements of detective fiction as suspense, secrecy, deception, and thriller-moments to maintain the reader's interest. After the first half of the novel, it is hinted that Danny is the murderer: the solution presented in the end follows logically and naturally, as Rick explains how the crime was solved, and the reader reaches the same conclusion that the detective does. The murderer, Danny, is not an ordinary, simple-minded person; his intelligence, professional success, well-contrived schemes, and physical attractiveness make him a worthy opponent of Rick. Although the author is not a Vietnamese American, he understands many aspects of Vietnamese culture, and his descriptions of Vietnamese homes and Vietnamese behavior demonstrate his close observations of the Vietnamese American community in Little Saigon. 
Thematically, Caught Dead employs the themes of opposition common to most detective fiction: trust versus betrayal, appearance versus reality, good intentions versus malevolence. The novel treats urban gang culture, drug culture, and familial and generational conflicts. Truth versus deception in communication is another important theme, as the children camouflage their drug addiction and sexual affairs through fabrication, circumlocution, and pretense to confuse and prevent suspicion from their parents. Psychologically, Larry is caught between the various antithetical themes - he would rather conceal Danny's crimes to protect his business than report him to the police; thus, Danny cleverly takes advantage of Larry's moral ambivalence to exercise control over him. The heinous nature of Danny's personality is masked under a veneer of his accomplishments as a Harvard graduate and success as a banker.

Rick, an Amerasian, feels alienated from and discriminated against by both the pureblooded Vietnamese people and the Americans who surround him. He is derogatorily referred to in Vietnamese as a bui boi (dust of life) - that is, as a product of the ignominious courtship between an ignoble Vietnamese woman and an unnamed American soldier. Like the majority of Amerasians who were culturally and linguistically rootless after their arrivals in the United States, Rick often "wake[s] up feeling lost and homeless." He says, "I am drifting in space, no rock to cling to. Helpless, screaming" (p. 26). However, he eventually comes to represent an "American success story" (p. 25).

Caught Dead debunks the myth of Asian Americans as the Model Minority, who excel in education, succeed in business, and abide by the law. Most of the Vietnamese characters in the novel do not understand the legal system in the United States, due to language barriers: "They can be a little nervous around cops" (p. 12), and "the Vietnamese don't vote" (p. 19). Their Little Saigon, according to the Hartford police force, is a "brand new geography," and its people are "inscrutable" (p. 19). It is Hank who navigates Rick around this ethnic enclave because Hank has the knowledge of its local people and culture. The seemingly peaceful Little Saigon, separated from the mainstream culture, is rocked by murder. Unlike the earlier Charlie Chan novels set in Honolulu that feature an Asian detective, Caught Dead relies much less upon stereotyped characters. It actually attempts to break stereotypes in order to reveal an essence in the "Americanness" of the characters.

\section{About the Reviewer}

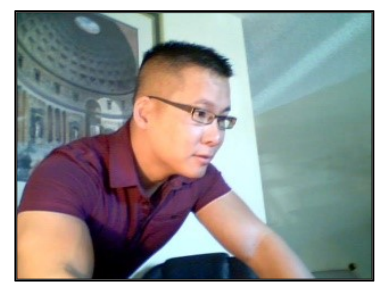

Quan Manh Ha, Ph.D., is Associate Professor of English at the University of Montana. His research interests primarily focus on 20thcentury and contemporary American literature, Vietnam War literature, ethnic studies, and literary translation. 


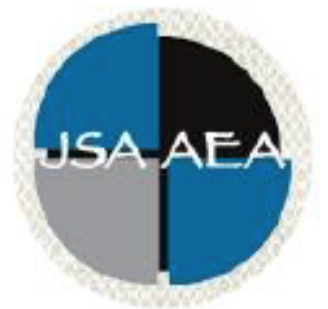

Volume 10 (2015)

\section{Journal of Southeast Asian American}

\section{Education and Advancement}

\author{
www.JSAAEA.org
}

\section{Editor}

Dr. Wayne E. Wright

Purdue University

\section{Associate Editors}

Dr. Chhany Sak-Humphry

University of Hawaii at Manoa

Dr. Phitsamay Sychitkokhong Uy

University of Massachusetts, Lowell

\section{Book Review Editor}

Dr. Vichet Chhuon

University of Minnesota

\section{Creative Works Editor \\ Bryan Thao Worra \\ Lao Assistance Center}

\section{Journal Manager \\ Marshall Klassen \\ Purdue University}

\section{Editorial Review Board}

\author{
Dr. Steve Arounsack \\ California State University, Stanislaus \\ Dr. Sovicheth Boun \\ The State University of New York at Fredonia \\ Dr. George Chigas \\ University of Massachusetts, Lowell \\ Dr. Hien Duc Do \\ San Jose State University \\ Dr. Sophal Ear \\ Occidental College \\ Dr. Jeremy Hein \\ University of Wisconsin, Eau Claire
}

\author{
Dr. Carl L. Bankston III \\ Tulane University \\ Dr. Phala Chea \\ Lowell Public Schools \\ Dr. Loan Dao \\ University of Massachusetts, Boston \\ Dr. Changming Duan \\ University of Missouri, Kansas City \\ Dr. Sothy Eng \\ Lehigh University \\ Dr. Vincent K. Her \\ University of Wisconsin, Eau Claire
}

SDRERISHISRESEREDDReaders are free to copy, display, and distribute this article, as long as the work is attributed to the author(s) and the Journal of Southeast Asian American Education \& Advancement, it is distributed for non-commercial purposes only, and no alteration or transformation is made in the work. More details of this Creative Commons license are available at http://creativecommons.org/licenses/by-nc-nd/3.0/. All other uses must be approved by the author(s) or JSAAEA. 


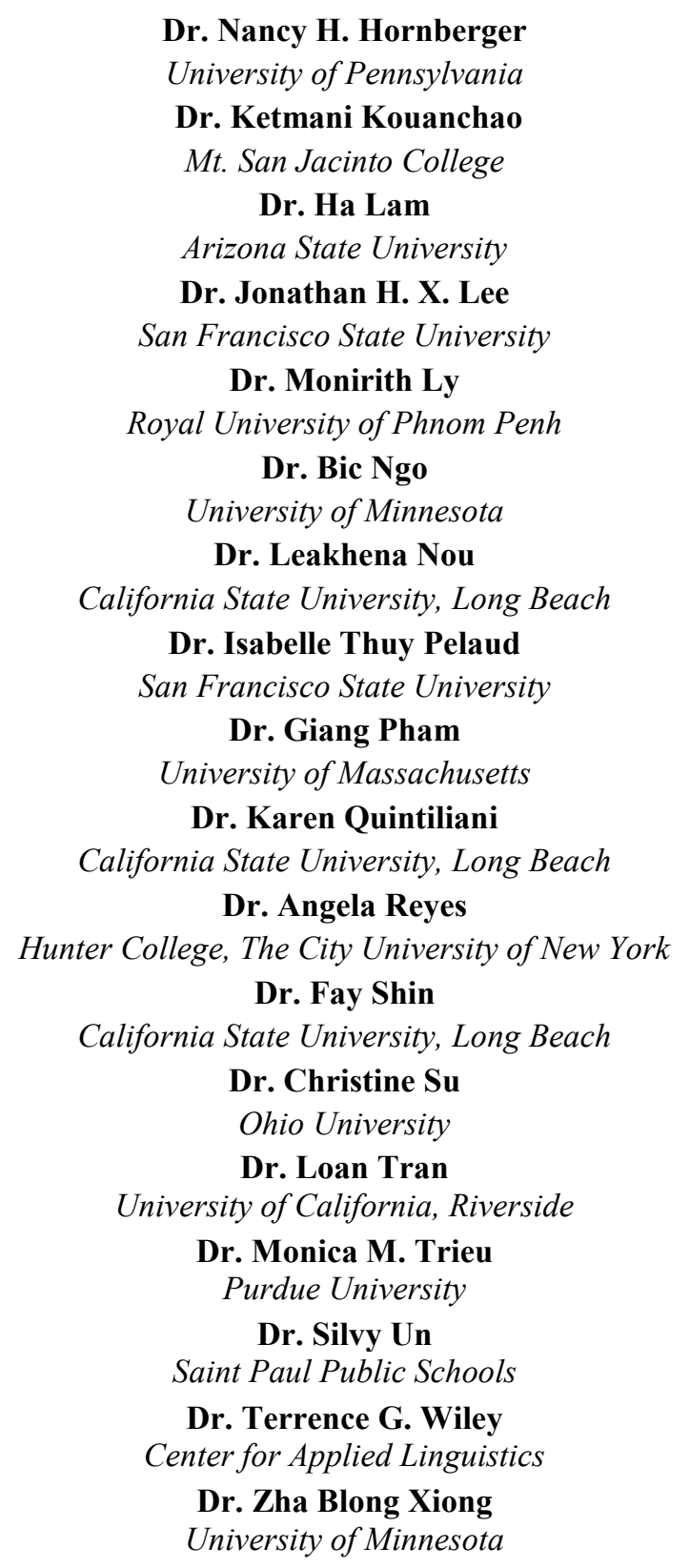

\author{
Dr. Peter Nien-Chu Kiang \\ University of Massachusetts, Boston \\ Dr. Kevin K. Kumashiro \\ University of San Francisco \\ Dr. Ravy Lao \\ California State University, Los Angeles \\ Dr. Stacey Lee \\ University of Wisconsin, Madison \\ Dr. Sue Needham \\ California State University, Dominguez Hills \\ Dr. Max Niedzwiecki \\ Daylight Consulting Group \\ Dr. Clara Park \\ California State University, Northridge \\ Dr. Mark Pfeifer \\ SUNY Institute of Technology \\ Dr. Loan T. Phan \\ University of New Hampshire \\ Dr. Kalyani Rai \\ University of Wisconsin, Milwaukee \\ Dr. Cathy J. Schlund-Vials \\ University of Connecticut, Storrs \\ Dr. Nancy J. Smith-Hefner \\ Boston University \\ Dr. Yer J. Thao \\ Portland State University \\ Dr. Tinou Tran \\ Alief Independent School District \\ Dr. Khatharya Um \\ University of California, Berkeley \\ Dr. Linda Trinh Vo \\ University of California, Irvine \\ Dr. Yang Sao Xiong \\ University of Wisconsin-Madison \\ Dr. Kou Yang \\ California State University, Stanislaus
}

\section{Doctoral Student Editorial Review Board}

\author{
Virak Chan \\ University of Texas at San Antonio \\ Annie BichLoan Duong \\ San Joaquin County Office of Education \\ Minh Mai \\ University of Wisconsin-Madison \\ Hoa Nha Nguyen \\ Boston College \\ Malaphone Phommasa \\ University of California, Santa Barbara
}

\author{
Keo Chea-Young \\ University of Pennsylvania \\ Peter Tan Keo \\ Columbia University \\ Dung Minh Mao \\ University of Minnesota \\ Thien-Huong Ninh \\ University of Southern California
}

Alisia Tran

University of Minnesota

Journal of Southeast Asian American Education \& Advancement, Vol. 10 (2015) 
Journal of Southeast Asian American Education and Advancement, Vol. 10 [2015], Iss. 1, Art. 3

Krissyvan Truong Claremont Graduate University

Soua Xiong

San Diego State University \& Claremont

Graduate University
Molly Wiebie

The University of Texas at Austin

Anna H. Yang

University of Georgia

\author{
Lesley Yang \\ University of Minnesota
}

Journal of Southeast Asian American Education \& Advancement, Vol. 10 (2015) 